\title{
Sportsmanship Behavioral Tendencies of the Students Athletes in Turkey: Ardahan Example
}

\author{
Abdullah Küşad Akbulut ${ }^{1}$ \\ ${ }^{1}$ School of Physical Education and Sport, Ardahan University, Ardahan, Turkey \\ Correspondence: Abdullah Küşad Akbulut, School of Physical Education and Sport, Ardahan University, \\ Ardahan, Turkey. E-mail: kursadakbulut@ardahan.edu.tr
}

\author{
Received: December 12, 2019 Accepted: January 10, 2020 Online Published: February 5, 2020 \\ doi:10.5539/jel.v9n2p76 URL: https://doi.org/10.5539/jel.v9n2p76
}

\begin{abstract}
The aim of this study is to analyze sportsmanship behavioral tendencies of the students of secondary education who are being schooled within the provincial center of Ardahan by taking several variables into consideration. In accordance with this aim, this study has been conducted through the survey modelling of quantitative research methods. For the data analysis, T-Testing and ANOVA are applied. According to the obtained findings, the sportsmanship level of student-sportsmen is revealed to be higher than student-sportswomen. In addition to this, the 1st question has the maximum value within the scale with the average value of 4.0248 . The minimum value, on the other hand, belongs to the 22nd question with the value of 2.9684. The general average of the scale is 3.4815, located in-between Agree-Not Sure. Consequently, it can be claimed that the perception and the level of sportsmanship are high. As a result, it is concluded that the sportsmanship level of the student-sportspeople residing in Ardahan is relatively high and that the sportsmen have a higher sportsmanship level compared to that of sportswomen.
\end{abstract}

Keywords: sports, fair play, sportsmanship, morals, ethics

\section{Introduction}

It is known that Fair-Play, which is widely used across the world and an English phrase, means "gentlemanship within sports" (Pehlivan, 2004). The concept of gentlemanship is commonly used as the notion of sportsmanship within our country. Sportsmanship is a concept that has the characteristics of fellowship, courage, patience, self-control, self-confidence, being non-disdainful towards others, respecting the ideas and morals of others, courtesy, kindness, nobility, honorableness, cooperation and generosity (Koç, 2013). Besides, sportsmanship can be described as the behaviors expected from the sportsmen and sportswomen (Türkmen \& Varol, 2015).

Sportsmanship applies to moral behavioral tendencies that suggest how to behave in accordance with the spirit of sports (Stornes \& Bru, 2002). The concept of sportsmanship is defined as an expression of competition and honesty as a responsible and considerate sportsperson. It is also described with such concepts as magnanimity, respect, kindness, affinity, affection, altruism and generosity (Stornes \& Ommundsen, 2004). With its simple definition, the concept of sportsmanship is related to how sportspeople are directed to the play (Balçıkanll, 2010).

The presence of the opponent should be paid attention within a civilized competition. Since there would be no competition and sport where there is no competitor, if those who compete with each other perceive one another as the reason for the existence of competition, therein, solidarity would be achieved (Erdemli, 2008, p. 116). This is why it is important for people who internalize the essence of sports and competition to rise against the unfair success during competitions (Simon, 1991, p. 45). Accordingly, sportive virtue (fair play) and sportsmanship have been kept in the forefront since the emergence of modern sports, but the participating sportspeople have not fully comprehended its importance (David, 2005, p. 225).

Today, sports are conducted professionally or unprofessionally. The aim of amateur sports is participation and is carried out in order to keep healthy, to be strong, to rest, to have fun, to have a good time and to retain social interaction (Sessions, 2004). In any case, the sports performed with the sole aim of winning, may lead the sportsperson to non-sportive methods in order to achieve his goal (Vallerand, \& Losier, 1994). When sports are performed for professional purposes, it leads to the development of unsportsmanlike conduct (Hon, 1994). The 
sports educators, on the other hand, are proud of the fact that sports have important contributions to character development. Relatedly, it is expected that a sportsperson would develop such sportsmanship features as justice, self-control and courage (Shields \& Bredemeier, 1995).

It would not be wrong to claim that specifically nowadays, the concepts of morals, fair play or gentlemanship have become crucial and foregrounded. As a matter of fact, it is observed that many researches have been carried out within the framework of sportsmanship today (Gürpınar \& Kurşun, 2013; Sevde \& Tuncel, 2012; Çalayır et al., 2017; Güllü \& Şahin, 2018).

\subsection{Purpose of the Study}

The aim of this study is to analyze sportsmanship behavioral tendencies of the students of secondary education who are being schooled within the provincial center of Ardahan by taking several variables into consideration. Within this context, the research is limited to the public schools located in Ardahan provincial center and affiliated to the Ministry of National Education in order to render detailed and comprehensive assessments.

\section{Method}

\subsection{Research Method}

While this study has been conducted through the survey modelling of quantitative research methods, during this process, a 5-point Likert scale has been applied as the data collection tool. While the quantitative research method, which is frequently utilized within scientific studies, aims to obtain objective, valid and reliable information, it also enables the representation of findings through their numerical values (Özsoy \& Madran, 2010, p. 191; Kuş, 2012, p. 105; Ekiz, 2003, p. 47). With the survey modelling, through which the detailed data is obtained from large groups (Büyüköztürk et al., 2017, p. 97), a profile is aimed to be constructed by using the words and numbers (Yıldırım \& Şimşek, 2016, p. 54). In addition, the relationship between the different characteristics of the research group can be examined in this process (Fraenkel et al., 2012, p. 121).

\subsection{Population and Sampling}

The population of this study consists of secondary education students who have been schooled in the region of Eastern Anatolia. The method of simple random sampling has been applied to reach a sufficiently large research group over this population. According to this method, a completely random, unbiased, simple and independent selection is carried out within the universe (Balc1, 2016, p. 74; Kaya \& Şahin, 2013, p. 24). Therefore, the research group of the study consists of 477 secondary school students who are educated in Ardahan provincial center and selected through the method of simple random sampling. Demographic characteristics of these students are presented by being visualized within the table below.

Table 1. Arithmetic means and standard deviations of the expressions in sportsmanship

\begin{tabular}{|c|c|c|c|c|c|c|c|}
\hline \multicolumn{2}{|c|}{ Demographic Characteristics } & \multirow{2}{*}{$\begin{array}{l}\mathrm{n} \\
41\end{array}$} & \multirow{2}{*}{$\begin{array}{l}\% \\
9.2\end{array}$} & \multicolumn{2}{|c|}{ Demographic Characteristics } & \multirow{2}{*}{$\begin{array}{l}\mathrm{n} \\
142\end{array}$} & \multirow{2}{*}{$\begin{array}{l}\% \\
32.1\end{array}$} \\
\hline Age & $13-14$ & & & Education Level of the & Primary & & \\
\hline & 15 & 95 & 21.4 & Father & Secondary & 229 & 51.7 \\
\hline & 16 & 139 & 31.4 & & Associate & 32 & 7.2 \\
\hline & 17 & 134 & 30.2 & & Graduate & 25 & 5.6 \\
\hline & 18 & 31 & 7.0 & & Masters & 13 & 2.9 \\
\hline & 19 & 2 & .5 & & Doctorate & 2 & .5 \\
\hline & 20 & 1 & .2 & Education Level of the & Primary & 219 & 49.4 \\
\hline \multirow[t]{2}{*}{ Gender } & Male & 268 & 52.8 & Mother & Secondary & 183 & 41.3 \\
\hline & Female & 209 & 47.2 & & Associate & 17 & 3.8 \\
\hline \multirow[t]{4}{*}{ Duration (Year) } & 1 & 268 & 60.5 & & Graduate & 12 & 2.7 \\
\hline & 2 & 56 & 12.6 & & Masters & 6 & 1.4 \\
\hline & 3 & 70 & 15.8 & & Doctorate & 6 & 1.4 \\
\hline & $4-9$ & 49 & 11.1 & Monthly Income (TL) & $0-499$ & 70 & 15.8 \\
\hline \multirow[t]{5}{*}{ Grade } & 9 & 126 & 28.4 & & $500-999$ & 46 & 10.4 \\
\hline & 10 & 138 & 31.2 & & $1000-1499$ & 93 & 21.0 \\
\hline & 11 & 125 & 28.2 & & $1500-1999$ & 47 & 10.6 \\
\hline & 12 & 54 & 12.2 & & $2000-2499$ & 66 & 14.9 \\
\hline & & & & & 2500 and above & 121 & 27.3 \\
\hline
\end{tabular}

As Table 1 is examined, it is identified that $9.2 \%$ of the participants is between the ages of $13-14(n=41), 21.4 \%$ of them is 15 years old $(n=95), 31.4 \%$ of them is 16 years old $(n=139), 30.2 \%$ is 17 years old $(n=134), 7 \%$ is 
18 years old $(\mathrm{n}=31), 0.5 \%$ is 19 years old $(\mathrm{n}=2)$ and $0.2 \%$ is 20 years old $(\mathrm{n}=1) .52 .8 \%$ of the students is male $(\mathrm{n}=268)$ and $47.2 \%$ is female $(\mathrm{n}=209)$. When the duration of sporting activities of the students is examined, $60.5 \%$ stated that they have been doing sports for more than 1 year, $12.6 \%$ for more than 2 years, $15.8 \%$ for more than 3 years and $11.1 \%$ for more than 4 years. $28.4 \%$ of the participants is in the ninth grade, $31.2 \%$ is in the tenth grade, $28.2 \%$ is in the eleventh grade and $12.2 \%$ is in the twelfth grade. When the education level of the fathers of the participants is examined, it is detected that

$32.1 \%$ has a primary education degree, $51.7 \%$ has a secondary education degree, $7.2 \%$ has an associate degree, $5.6 \%$ has a bachelor's degree, $2.9 \%$ has a master's degree and $0.5 \%$ has a doctorate degree. When the education level of the mothers of the participants is examined, it is detected that $49.4 \%$ has a primary education degree, $41.3 \%$ has a secondary education degree, $3.8 \%$ has an associate degree, $1.4 \%$ has a master's degree and $1.4 \%$ has a doctorate degree. As to the monthly income of the family, $15.8 \%$ is between the range of $0-449 \mathrm{TL}, 10.4 \%$ is between 500-999 TL, 21\% is between 1000-1499 TL, 10.6\% is between 1500-1999 TL, 14.9\% 2000-2499 TL and $27.3 \%$ is between the range of $2500 \mathrm{TL}$ and above.

\subsection{Data Collection Tool}

As the data collection tool of the study, "Physical Education Course Sportmanship Behavior Scale" developed by Koç (2013) is utilized. The confirmatory factor analysis and Cronbach's Alpha reliability analysis are conducted in order to prove the structural validity and reliability of the scale with the current research data since the scale was developed by Koç through the data obtained from secondary school students.

\subsection{Data Analysis}

In accordance with the aim of the study, the obtained data have been analyzed via SPSS 22 program at $95 \%$ confidence interval range. Descriptive statistics (frequency, percentage, average, standard deviation) have primarily been utilized in this process. Then, it is assessed whether the data reveal normal distribution before the relationship tests in-between groups or not, and thereafter, the parametric testing techniques of T-Test and ANOVA analysis are conducted because the data reveal normal distribution. The values obtained from the results of the normality test are presented in the table below.

\section{Results}

In this part of the study, in accordance with the aim of the research, the findings attained through various analysis methods are presented by visualizing them via numerical data and the results have been interpreted separately.

Table 2. Arithmetic means and standard deviations of the expressions in sportsmanship behavior scale

\begin{tabular}{llllll}
\hline & $\mathrm{N}$ & $\min$ & $\max$ & a.ave & s.s \\
\hline Question 1 & 443 & 1.00 & 5.00 & 4.0248 & 1.29804 \\
Question 2 & 443 & 1.00 & 5.00 & 3.6637 & 1.32406 \\
Question 3 & 443 & 1.00 & 5.00 & 3.1354 & 1.54119 \\
Question 4 & 443 & 1.00 & 5.00 & 3.4470 & 1.39286 \\
Question 5 & 443 & 1.00 & 5.00 & 3.1648 & 1.44818 \\
Question 6 & 443 & 1.00 & 5.00 & 3.4515 & 1.53224 \\
Question 7 & 443 & 1.00 & 5.00 & 3.5485 & 1.42514 \\
Question 8 & 443 & 1.00 & 5.00 & 2.8262 & 1.40266 \\
Question 9 & 443 & 1.00 & 5.00 & 3.5621 & 1.38760 \\
Question10 & 443 & 1.00 & 5.00 & 3.3183 & 1.58051 \\
Question11 & 443 & 1.00 & 5.00 & 3.5937 & 1.40528 \\
Question12 & 443 & 1.00 & 5.00 & 3.7698 & 1.36249 \\
Question13 & 443 & 1.00 & 5.00 & 3.4786 & 1.51355 \\
Question14 & 443 & 1.00 & 5.00 & 3.6343 & 1.41482 \\
Question15 & 443 & 1.00 & 5.00 & 3.3815 & 1.59363 \\
Question16 & 443 & 1.00 & 5.00 & 3.5824 & 1.41080 \\
Question17 & 443 & 1.00 & 5.00 & 3.7111 & 1.52877 \\
Question18 & 443 & 1.00 & 5.00 & 3.4199 & 1.55728 \\
Question19 & 443 & 1.00 & 5.00 & 3.6907 & 1.41791 \\
Question20 & 443 & 1.00 & 5.00 & 3.6727 & 1.57292 \\
Question21 & 443 & 1.00 & 5.00 & 3.5553 & 1.41533 \\
Question22 & 443 & 1.00 & 5.00 & 2.9684 & 1.55266 \\
General Avarage & & & & 3.4815 & \\
\hline
\end{tabular}


As Table 2 is examined, it is identified that 1 st question has the highest value with an average of 4.0248 . The lowest value belongs to the 22nd question with the value of 2.9684 . The general average of the scale is in-between agree-not sure, with the value of 3.4815. The questions, 3, 6, 8, 10, 13, 15, 17, 18, 20, 22 are reverse coded in the questionnaire form. The table demonstrates the revised version.

Table 3. The demographic characteristics and T-test and ANOVA results of the expressions

\begin{tabular}{|c|c|c|c|c|c|}
\hline & & $\mathrm{n}$ & a. ave. & $\mathrm{t} / \mathrm{F}$ & $\mathrm{p}$ \\
\hline \multirow[t]{2}{*}{ Gender } & Male & 234 & 3.6156 & 4.400 & $.000^{*}$ \\
\hline & Female & 209 & 3.3321 & & \\
\hline \multirow[t]{5}{*}{ Age } & 14.00 & 41 & 3.4401 & 1.830 & .122 \\
\hline & 15.00 & 95 & 3.6187 & & \\
\hline & 16.00 & 139 & 3.4683 & & \\
\hline & 17.00 & 134 & 3.4033 & & \\
\hline & 18.00 & 34 & 3.5147 & & \\
\hline \multirow[t]{4}{*}{ Duration (Year) } & $1-2$ & 268 & 3.4963 & .287 & .835 \\
\hline & $3-5$ & 56 & 3.4675 & & \\
\hline & $6-8$ & 70 & 3.4734 & & \\
\hline & 9 and above & 49 & 3.4314 & & \\
\hline \multirow[t]{4}{*}{ Education Level of the Father } & Primary & 142 & 3.5739 & 2.509 & .058 \\
\hline & Secondary & 229 & 3.4704 & & \\
\hline & Associate & 32 & 3.4205 & & \\
\hline & Graduate and above & 40 & 3.2693 & & \\
\hline \multirow[t]{3}{*}{ Education Level of the Mother } & Primary & 219 & 3.5162 & .289 & .749 \\
\hline & Secondary & 183 & 3.4650 & & \\
\hline & Graduate & 41 & 3.3736 & & \\
\hline \multirow[t]{4}{*}{ Grade } & 9 & 126 & 3.4942 & .714 & .544 \\
\hline & 10 & 138 & 3.5152 & & \\
\hline & 11 & 125 & 3.4036 & & \\
\hline & 12 & 54 & 3.5488 & & \\
\hline \multirow[t]{6}{*}{ Income } & $0-499$ & 70 & 3.4448 & .520 & .761 \\
\hline & $500-999$ & 46 & 3.3488 & & \\
\hline & $1000-1499$ & 93 & 3.5870 & & \\
\hline & 1500-1999 & 47 & 3.5126 & & \\
\hline & $2000-2499$ & 66 & 3.5145 & & \\
\hline & 2500 and above & 121 & 3.4433 & & \\
\hline
\end{tabular}

When Table 3 is examined, it is revealed that there is a significant difference in sportsmanship behavior basing on the gender. Men have higher sportsmanship behavior compared to women. There is no significant difference between other demographic characteristics. Since there was a student from the 5 th grade, s/he was included in the upper grade. Since the number of the participants from the age range of 19 and 20 was low, they have been analyzed as 18 and above. Due to the small number of fathers and mothers with post-graduate degrees was low, they have been combined as post-graduates.

\section{Discussion}

At this part of the study, the research results are discussed in the light of the data in the current literature and evaluations regarding sportsmanship behavior levels of the students are presented.

When the research results are assessed, it is identified that the 1st question has the highest value with an average of 4.0248. The lowest value belongs to the 22nd question with the value of 2.9684. The general average of the scale is in-between agree-not sure, with the value of 3.4815. Therefore, it can be claimed that the perception and level of sportsmanship is high. It was identified in a study by Tel et al. (2017) that the sportsmanship behaviors of the students from the Faculty of Sport Sciences were lower (intermediate level) than expected. It can be asserted that although the students' awareness of sportsmanship behavior is moderate, it is still not sufficient. In another study, it was determined that the sportsmanship behaviors of secondary school students were again moderate (Hacicaferoğlu et al., 2015).

When the results of the study are analyzed, only a significant difference has been detected in terms of gender variable. There is no statistically significant difference in terms of age, sporting duration, fatherly and motherly education levels, grade and income level. Accordingly, the level of sportsmanship behavior of men is higher than 
women. The high rate of male-student participation in sports competitions can be considered as the first factor for the emergence of this situation. Additionally, the lower competitive environment in women's sports compared to men can be interpreted as another factor.

In a study conducted by Gürpınar and Kurşun (2013), it was found that the differences by gender were not significant, although along with this, it was identified that women's sportsmanship scores were higher than those of men.

Duda et al. (1991) demonstrate that sportsmanship scores varied according to gender. In their studies on handball and football, Coulomb-Cabagno and Rascle (2006) conclude that men are more aggressive than women. Tsai and Fung (2005) also put forward that women care about sporting more than men. Tucker and Parks (2001) assert that women's aggressive behavior scores are lower than that of men.

In this context, contrary to the literature, the results of the study demonstrate that the student-sportsmen exhibit a more sportsmanly attitude than the sportswomen. As this research is limited to Ardahan, it is highly difficult to generalize the results. However, it would not be wrong to assert that the study reveals some clues specific to Ardahan. In today's competitive atmosphere, it highly crucial to raise the awareness of sportspeople, especially sportspeople being schooled, about sportsmanship, morals, ethics and so on, in order to direct their future sports life. Along with this, expanding the results of the research and conducting studies with larger sample groups may increase the generalizability of the results and allow more concrete steps to be taken.

\section{References}

Balc1, A. (2016). Sosyal Bilimlerde Araştırma Yöntem, Teknik Ve İlkeler. Ankara: Pegem Yayıncılık.

Balçıkanlı, G. (2010). Çok boyutlu sportmenlik yönelimi ölçeği’nin Türkçe uyarlaması: geçerlik ve güvenirlik çalışması. Gazi Beden Eğitimi ve Spor Bilimleri Dergisi, XV(1), 1-10.

Büyüköztürk, Ş., Çakmak, E. K., Akgün, E. Ö., Karadeniz, Ş., \& Demiral, F. (2017). Bilimsel Araştırma Yöntemleri. Ankara: Pegem Yayınc1lk. https://doi.org/10.14527/9789944919289

Çalayır, Ö., Yıldız, N., Yaldız, Ö., \& Çoknaz, H. (2017). Hokey müsabakalarına katılan sporcuların beden eğitimi dersi sportmenlik davranışlarının incelenmesi. İstanbul Üniversitesi Spor Bilimleri Dergisi, 7(2), $27-37$.

Coulomb-Cabagno, G., \& Rascle, O. (2006). Team sports players observed aggresion as a function of gender competitive level and sport type. Journal of Applied Social Psychology, 36(8), 1980-2000. https://doi.org/10.1111/j.0021-9029.2006.00090.x

David, P. (2005). Human Rights in Youth Sport. London: Routledge.

Duda, J. L., Olson, L. K., \& Templin, T. J. (1991). The relationship of task and ego orientation to sportsmanship attitudes and the perceived legitimacy of injurious acts. Research Quarterly for Exercise and Sport, 62, 7987. https://doi.org/10.1080/02701367.1991.10607522

Ekiz, D. (2003). Eğitimde Araştırma Yöntem Ve Metotlarına Girişs. Ankara: Anı Yayıncılık.

Erdemli, A. (2008). Spor Yapan İnsan. İstanbul: E Yayınları.

Fraenkel, J. R., Wallen, N. E., \& Hyun, H. H. (2012). How to Design 8 Evaluate Research in Education. London: McGraw Hill.

Güllü, S., \& Şahin, S. (2018). Milli güreşçilerin sportmenlik yönelim düzeyleri üzerine bir araştırma. Electronic Turkish Studies, 13(18), 705-718. https://doi.org/10.7827/TurkishStudies.14152

Gürpınar, B., \& Kurşun, S. (2013). Basketbolcuların ve futbolcuların sportmenlik yönelimleri. Mediterranean Journal of Humanities, 3(1), 171-176. https://doi.org/10.13114/MJH/20131660

Hacıcaferoğlu, S., Selçuk, M. H., Hacıcaferoğlu, B., \& Karataş, Ö. (2015). Ortaokullarda işlenen beden eğitimi ve spor derslerinin, sportmenlik davranışlarına katkısının bazı değişkenler açısından incelenmesi. International Journal of Science Culture and Sport, 4, 557-566.

Hon, J. (1994). Teaching fair play: the essence of sport. Journal of Physical Education, 65(7), 70-73. https://doi.org/10.1080/07303084.1994.10606969

Kaya, Z., \& Şahin, M. (2013). Meslek Yüksekokulları İçin Araştırma Yöntemleri Ve Teknikleri. Konya: Eğitim Yayınevi.

Koç, Y. (2013). Beden eğitimi dersi sportmenlik davranışı ölçeği (BEDSDÖ): Geçerlik ve güvenirlik çalışması. Erzincan Üniversitesi Ĕgitim Fakültesi Dergisi, 15(1), 96-114. 
Kuş, E. (2012). Nicel-Nitel Araştırma Teknikleri. Ankara: Anı Yayıncılık.

Özsoy, T., \& Madran, C. (2010). Reklam Teknik Analizi: Reklamda Kadın. Ankara: Pegem Yayınları.

Pehlivan, Z. (2004). Fair-play kavramının geliştirilmesinde okul sporunun yeri ve önemi. SPORMETRE Beden Eğitimi ve Spor Bilimleri Dergisi, II(2), 49-53. https://doi.org/10.1501/Sporm_0000000028

Sessions, W. L. (2004). Sportsmanship as honor. Journal of the Philosophy of Sport, 31(1), 47-59. https://doi.org/10.1080/00948705.2004.9714648

Sevde, M., \& Tuncel, S. D. (2012). Sporcuların sporda hoşgörü kavramına ilişkin algıları. SPORMETRE Beden Eğitimi ve Spor Bilimleri Dergisi, 10(4), 125-129. https://doi.org/10.1501/Sporm_0000000229

Shields, D. L., \& Bredemeier, B. J. (1995). Character Development and Physical Activity. Champaign, IL: Human Kinetics.

Simon, R. L. (1991). Fair Play: Sports Values and Society. Colorado: Westview Press.

Stornes, T., \& Bru, E. (2002). Sportspersonship and perceptions of leadership: an investigation of adolescent handball players' perception of sportspersonship and associations with perceived leadership. European Journal of Sport Science, 2(6), 1-15. https://doi.org/10.1080/17461391.2002.10142577

Stornes, T., \& Ommundsen, Y. (2004). Achievement goals, motivational climate and sportspersonship: a study of yound handball players. Scandinavian Journal of Education, 48(2), 205-221. https://doi.org/10.1080/0031383042000198512

Tel, M., Yaman, Ç., \& Altun, M. (2017). Spor bilimleri fakültesi öğrencilerinin sportmenlik davranışları hakkındaki görüşleri. International Journal of Cultural and Social Studies, 3, 16-26.

Tsai, E., \& Fung, L. (2005). Sportspersonship in youth basketball and volleyball players. Athletic Insight: The Online Journal of Sport Psychology, 7(2), 37-46.

Tucker, L. W., \& Parks, J. B. (2001). Effects of gender and sport type on intercollegiate athletes' perceptions of the legitimacy of aggressive behaviors in sport. Sociology of Sport Journal, 18, 403-413. https://doi.org/10.1123/ssj.18.4.403

\section{Copyrights}

Copyright for this article is retained by the author, with first publication rights granted to the journal.

This is an open-access article distributed under the terms and conditions of the Creative Commons Attribution license (http://creativecommons.org/licenses/by/4.0/). 